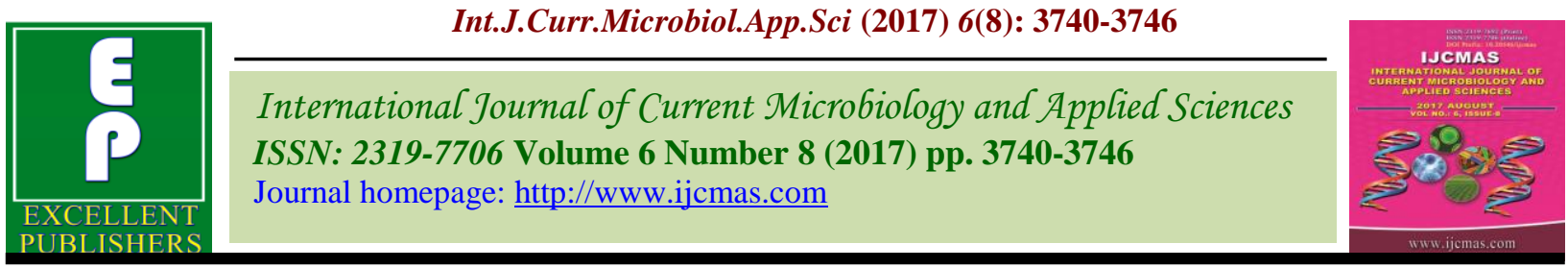

Original Research Article

https://doi.org/10.20546/ijcmas.2017.608.451

\title{
Effect of Herbal Immunomodulator on Immune Organ and Immunological Parameters in Giriraja Birds
}

\author{
G.Y. Dharmaraj*, Jayanaik, H.C. Indresh and T. Munegowda \\ Department of Poultry Science, Veterinary College, Hebbal, Bangalore, Karnataka, India \\ *Corresponding author
}

\section{A B S T R A C T}

Keywords

Herbal

Imunomodulator,

Levomisole,

Immune organs,

Antibody titer,

$\mathrm{H}$ : L ratio.

Article Info

Accepted:

21 June 2017

Available Online:

10 August 2017
An experiment was conducted to evaluate the effects of Herbal immunomodulator powder and liquid form (with and without vaccine) comparing with Levamisole powder (with and without vaccine) on immune organ weights and immunological parameters in Giriraja birds. In a completely randomised design, 525 day old Giriraja chicks were assigned to seven treatments with each treatment group consisting of five replicates with 15 chicks each. The results of the present study found that the dietary supplementation group had non-significant difference in relative weights of Spleen, Bursa of Fabricicus among the various treatment groups and thymus exhibited significant difference in herbal immunomodulator powder supplemented group $\left(\mathrm{T}_{4}\right.$ and $\left.\mathrm{T}_{5}\right)$ among themselves. Significant effect in antibody titer against NDV showed during $21^{\text {st }}$ day of age, levamisole supplemented group $\left(\mathrm{T}_{2}\right.$ and $\left.\mathrm{T}_{3}\right)$ and herbal immunomodulator powder supplemented group ( $\mathrm{T}_{4}$ and $\mathrm{T}_{5}$ ) exhibited significant difference among themselves and herbal immunomodulator liquid supplemented group $\left(\mathrm{T}_{6}\right.$ and $\left.\mathrm{T}_{7}\right)$ exhibited non- significant difference among themselves. The non- significant difference during $56^{\text {th }}$ day of age, the titer value against IBD showed significant difference during $56^{\text {th }}$ day of age in treatment groups $\left(\mathrm{T}_{2}, \mathrm{~T}_{6}\right.$ and $\left.\mathrm{T}_{7}\right)$ and no significant difference on $\mathrm{H}$ : $\mathrm{L}$ ratio was observed.

\section{Introduction}

Poultry rearing is currently the fast growing industry in National livestock sector with its benefits in the form of increased and economic production and provision of proteinaceous food. In India, poultry industry is recognized as an important cottage as well as fast growing large commercial agriculture industry. Sustained economically viable poultry production demands the stringent control of various infectious diseases affecting the birds which result in huge economic losses to the poultry farm owners (Ganguly and Prasad, 2010). Nutrient requirements varies proportionately with the rate of growth, age of the bird, sex and genotype (breed or strain). Poultry nutritionists in India are adopting BIS or NRC recommendations in formulating rations for different age group of chicken. The carcass quality is an important characteristic from the view point of consumer's preference and acceptance of meat. Characterization and evaluation of immune parameters in Giriraja, Swarnadhara, Vanaraja and genotypes can offer knowledge that can be incorporated into breeding programmes for enhancing the natural resistance to disease in tropical and subtropical environment. 
The use of natural feed additives as substitutes for antibiotic in poultry production has become an area of great interest. Medicinal plants or herbs consists of many pharmacologically active chemical compounds which have antimicrobial activity, antioxidant activity, antifungal activity, antiviral activity, anti-inflammatory effects as well as immunomodulatory properties (Toghyani et al., 2015).

\section{Materials and Methods}

Five hundred and twenty five day old straight run Giriraja chicks from a single hatch were wing banded for identification, weighed and randomly distributed to seven treatment groups in Completely Randomised Design. Each treatment had five replicates with 15 birds in each replicate.

All the experimental chicks were healthy and received normal routine health care during eight weeks of the trial. The birds were provided feed and water ad libitum. A practical diet comprising of Yellow Maize, Soya bean meal, feed supplements and feed additives without antibiotics and coccidiostat constituted the control diet for all the seven treatment groups. The feed for the treatment group was formulated as per BIS (1994) requirements for all the nutrients except antibiotics and coccidiostat. The experimental birds in $\mathrm{T}_{1}$ were fed with control diet without any antibiotics and coccidiostat.

The birds were administered with ND and IBD vaccines. The experimental birds in $T_{2}$ were fed as in $T_{1}$ and supplemented with Levamisole powder. The experimental birds in $\mathrm{T}_{3}$ were fed as in $\mathrm{T}_{2}$ and administered vaccines. The experimental birds from $\mathrm{T}_{4}$ and $\mathrm{T}_{5}$ were fed with Herbal Immunomodulator preparation in powder form containing Mandukaparni, Yasthi madhu, Guduchi, vriddadaru, Amalaki, Nimba and etc without and with vaccines, respectively and birds from $\mathrm{T}_{6}$ and $\mathrm{T}_{7}$ were fed with Herbal Immunomodulator preparation in liquid form containing Himsara, Kasani, Vasaka, Guduchi, Daraksha, Jhavuka, Shatavari etc., without and with administration of vaccines, respectively against ND and IBD.

\section{Results and Discussion}

\section{Immunological parameters}

The results of the effect of immune response of supplementing herbal immunomodulator in both powder and liquid form (with and without vaccine) and levamisole powder (with and without vaccine) on immunological parameters in Giriraja birds are presented in this article.

\section{Immune organs (spleen, thymus and bursa)}

\section{Spleen}

The results mean and standard errors of the relative weight of spleen for immunomodulators in Giriraja birds at $56^{\text {th }}$ day of experimental period are presented in Table 2. Among the various treatment groups $\mathrm{T}_{3}$ (levamisole with vaccine) showed maximum relative weight of 0.22 as against the lowest weight of 0.19 in $\mathrm{T}_{6}$ (herbal immunomodulator liquid without vaccine) and control $\left(\mathrm{T}_{1}\right)$. Statistical analysis revealed non-significant difference in relative weights among the various treatment groups

\section{Bursa of fabricicus}

The mean and standard errors of the relative weight of bursa of Fabricicus for immunomodulators in Giriraja birds at $56^{\text {th }}$ day of experimental period is presented in table 1. The relative mean weight of bursa of Fabricicus ranged from 0.056 per cent in herbal immunomodulator $\left(\mathrm{T}_{6}\right.$ and $\left.\mathrm{T}_{7}\right)$ to 0.099 
per cent in herbal immunomodulator $\left(\mathrm{T}_{4}\right)$. Statistical analysis revealed non-significant difference in relative weights among the various treatment groups.

\section{Thymus}

The mean and standard errors of the relative weight of thymus for immunomodulators in Giriraja birds at $56^{\text {th }}$ day of experimental period is presented in table 1 .

Among the various treatment groups $T_{3}$ (levamisole with vaccine) showed maximum relative weight of thymus (0.56) as against the lowest weight of 0.36 in $\mathrm{T}_{5}$ (herbal immunomodulator powder with vaccine). The highest relative weight of 0.56 per cent recorded in levamisole with vaccine $\left(\mathrm{T}_{3}\right)$ and significantly higher compared to 0.36 observed in herbal immunomodulator powder with vaccine supplemented group $\left(\mathrm{T}_{5}\right)$ and non- significantly comparable with other treatment groups $\left(\mathrm{T}_{1} \mathrm{~T}_{2} \mathrm{~T}_{4} \mathrm{~T}_{6}\right.$ and $\left.\mathrm{T}_{7}\right)$.

However, levamisole supplemented group $\left(\mathrm{T}_{2}\right.$ and $\mathrm{T}_{3}$ ) and herbal immunomodulator liquid supplemented group $\left(\mathrm{T}_{6}\right.$ and $\left.\mathrm{T}_{7}\right)$ exhibited non- significant difference among themselves and herbal immunomodulator powder supplemented group $\left(\mathrm{T}_{4}\right.$ and $\left.\mathrm{T}_{5}\right)$ exhibited significant difference among themselves.

\section{Haemagglutination inhibition titer against Newcastle disease}

The results of the effect of supplementing herbal immunomodulators powder and liquid form (with and without vaccine) and levamisole powder (with and without vaccine)on Haemagglutination inhibition titer against Newcastle disease vaccine after vaccinating the birds at $7^{\text {th }}$ and $21^{\text {st }}$ day of age are presented in tables 2 . The analysis of variance remained significant $(\mathrm{P}>0.05)$ among various treatment groups at $7^{\text {th }}$ and remained non- significant at $21^{\text {st }}$ of day of vaccination.
The mean HI titer value analysed on $21^{\text {st }}$ day of the experiment which were vaccinated on $7^{\text {th }}$ day of age was significantly highest (23.60units) in group supplemented with levamisole with vaccine $\left(\mathrm{T}_{3}\right)$ compared to 3.60 units recorded in group supplemented with levamisole without vaccine $\left(\mathrm{T}_{2}\right)$ and 3 units recorded in group supplemented with herbal immunomodulator powder without vaccine $\left(\mathrm{T}_{4}\right)$ and 2.80 units recorded in group supplemented with herbal immunomodulator liquid without vaccine $\left(\mathrm{T}_{6}\right)$. However, the highest titer value recorded in group supplemented with levamisole powder with vaccine $\left(\mathrm{T}_{3}\right)$ was non- significantly comparable with other treatments $\left(\mathrm{T}_{1}, \mathrm{~T}_{5}\right.$ and $\mathrm{T}_{7}$ ). The lowest HI titer value (2.80 units) was observed in group supplemented with HIM liquid without vaccine $\left(\mathrm{T}_{6}\right)$ and significantly different from other treatment groups $\left(\mathrm{T}_{1}, \mathrm{~T}_{3}\right.$, $\mathrm{T}_{5}$ and $\mathrm{T}_{7}$ ). However, levamisole supplemented group $\left(\mathrm{T}_{2}\right.$ and $\left.\mathrm{T}_{3}\right)$ and herbal immunomodulator powder supplemented group $\left(\mathrm{T}_{4}\right.$ and $\left.\mathrm{T}_{5}\right)$ exhibited significant difference among themselves and herbal immunomodulator liquid supplemented group ( $\mathrm{T}_{6}$ and $\left.\mathrm{T}_{7}\right)$ exhibited non- significant difference among themselves. However, different herbal immunomodulator administered with vaccine showed highest HI titer and comparable among themselves.

The means of HI titer value analyzed on $56^{\text {th }}$ day of experiment which were vaccinated on $21^{\text {st }}$ day of age for $T_{1}, T_{2}, T_{3}, T_{4}, T_{5}, T_{6}$ and $T_{7}$ were $13.80,6.60,9.40,11.40,9.20,4.80$ and 9.20 units, respectively.

The non significantly highest $\mathrm{HI}$ titer value was recorded in control $\left(\mathrm{T}_{1}\right)$ and the lowest HI titre value was observed in group supplemented with herbal immunomodulator liquid without vaccine $\left(\mathrm{T}_{6}\right)$. Apparently, the above results indicated that herbal immunomodulator and levamisole did not have any significant effect $(\mathrm{P}>0.05)$ on $\mathrm{HI}$ titer value when compared to control and 
among the other treatment groups at the end of $56^{\text {th }}$ day of experiment.

\section{Antibody titer against IBD}

The results of the effect of herbal immunomodulator powder and liquid form (with and without vaccine) and levamisole powder (with and without vaccine) on antibody titer against Infectious Bursal Disease vaccine after vaccinating the birds on $14^{\text {th }}$ and $28^{\text {th }}$ day of experiment and which were analyzed on $21^{\text {st }}$ and $56^{\text {th }}$ day of experiment are presented in tables 3 .

The analysis of variance remained non significant $(\mathrm{P}>0.05)$ during $21 \mathrm{st}$ day of serum samples and significant $(\mathrm{P} \leq 0.05)$ during $56^{\text {th }}$ day of serum samples of various treatment groups at $14^{\text {th }}$ and $28^{\text {th }}$ day of post immunisation.

The non-significantly lowest mean antibody titer value (1921.00) was revealed on $14^{\text {th }}$ day of post immunization in group supplemented with herbal immunomodulator liquid with vaccine $\left(\mathrm{T}_{7}\right)$ and the highest mean antibody titer value (2374.60) was recorded in group supplemented with herbal immunomodulator liquid without vaccine $\left(\mathrm{T}_{6}\right)$. Statistical analysis revealed no significant difference in mean antibody titer values among different treatment groups.

The mean antibody titer value on $56^{\text {th }}$ day of age was highest (2236.10) in group supplemented with herbal immunomodulator liquid with vaccine $\left(\mathrm{T}_{7}\right)$ followed by 2201.20 in group supplemented with levamisole without vaccine $\left(\mathrm{T}_{2}\right), 2167.30$ in group supplemented with herbal immunomodulator liquid without vaccine $\left(\mathrm{T}_{6}\right), 2016.80$ in group supplemented with herbal immunomodulator powder with vaccine $\left(\mathrm{T}_{5}\right)$, and 1829.60 in group supplemented with levamisole with vaccine $\left(T_{3}\right)$. The highest antibody titer recorded in $T_{7}$ was significantly higher compared to $\mathrm{T}_{4}$ and $\mathrm{T}_{1}$ and non- significant with other treatment groups $\left(T_{2}, T_{3}, T_{5}\right.$ and $\mathrm{T}_{6}$ ).

However, levamisole supplemented group $\left(\mathrm{T}_{2}\right.$ and $\mathrm{T}_{3}$ ) showed non- significantly comparable antibody titer among themselves.

The lowest antibody titre value (1721.40) was observed in group supplemented with herbal immunomodulator powder without vaccine $\left(\mathrm{T}_{4}\right)$ and non significantly comparable with 1684.90 antibody titer value observed in control $\left(\mathrm{T}_{1}\right), 1829.60$ antibody titer value observed in group supplemented with levamisole with vaccine $\left(\mathrm{T}_{3}\right)$ and 2016.80 antibody titer value observed in group supplemented with herbal immunomodulator powder with vaccine $\left(\mathrm{T}_{5}\right)$. However, significantly different from treatment groups $\left(\mathrm{T}_{2}, \mathrm{~T}_{6}\right.$ and $\left.\mathrm{T}_{7}\right)$. Apparently, the above results indicated that herbal immunomodulator and levamisole have significant effect $(\mathrm{P}<0.05)$ on antibody titer against IBD compared to control and also among various treatment groups.

\section{Heterophill and lymphocyte ratio}

The data on supplementing herbal immunomodulator powder and liquid (with and without vaccine) and levamisole powder (with and without vaccine) in Girirraja birds is presented in table 4. Statistical analysis revealed non- significant difference compared to control on heterophill and lymphocyte ratio.

Among the various treatment groups, highest $\mathrm{H}: \mathrm{L}$ value $(0.14)$ was recorded in control fed group $\left(\mathrm{T}_{1}\right)$ as against the lowest value $(0.005)$ recorded in group supplemented with herbal immunomodulator liquid without and with vaccine $\left(\mathrm{T}_{6}\right.$ and $\left.\mathrm{T}_{7}\right)$. 


\section{Immunological parameters}

\section{Immune organs}

\section{Spleen and bursa}

There was no significant difference in relative weights of lymphoid organs viz., spleen and bursa in Giriraja birds due to supplementation of herbal immunomodulator powder and liquid form (with and without vaccine) and levamisole powder (with and without vaccine). The results are in contrary to the findings results of Durrani et al., (2006), who found that inclusion of turmeric powder increased the spleen weight and whole giblets weight of broilers.

\section{Thymus}

There was significant difference in relative weight of lymphoid organ viz., thymus in Giriraja birds by supplementation of herbal immunomodulator powder without vaccine $\left(\mathrm{T}_{4}\right)$ and levamisole powder with vaccine $\left(\mathrm{T}_{3}\right)$. The results of present study are in agreement with the findings of Al-Sultan (2003) who found that the higher thymus weight indices were detected in birds received diet containing $0.5 \%$ turmeric.

\section{HI titre against New Castle disease}

Immunological studies using ND vaccine showed significantly higher $\mathrm{HI}$ titer values at $21^{\text {st }}$ day of age in groups fed with the levamisole powder with vaccine $\left(\mathrm{T}_{3}\right)$ and herbal immunomodulator powder with vaccine groups $\left(T_{5}\right)$ when compared to other group supplemented with herbal immunomodulator. The results are similar to Ziaran et al., (2005), who reported that lower doses of plant extract in broilers had a positive antibody titer against ND, while the negative effects at higher levels.

\section{Antibody titer against IBD}

Immunological studies using IBD vaccine showed significantly higher antibody titer values at $8^{\text {th }}$ weeks of age in groups fed with herbal immunomodulator liquid $\left(\mathrm{T}_{6}\right.$ and $\left.\mathrm{T}_{7}\right)$ and levamisole powder without vaccine group $\left(\mathrm{T}_{2}\right)$. The analysis of variance remained non significant $(\mathrm{P}>0.05)$ during 21 st day of serum samples and significant $(\mathrm{P} \leq 0.05)$ during $56^{\text {th }}$ day of serum samples of various treatment groups at both $14^{\text {th }}$ and $28^{\text {th }}$ day of age of post immunisation. Non-significantly lowest mean antibody titer value (1921.00) on $14^{\text {th }}$ day of post immunization was recorded in group supplemented with herbal immunomodulator liquid with vaccine $\left(\mathrm{T}_{7}\right)$ and the highest mean antibody titer value (2374.60) was recorded in group supplemented with herbal immunomodulator liquid without vaccine $\left(\mathrm{T}_{6}\right)$. Statistical analysis revealed nonsignificant difference in mean antibody titer values among different treatment groups. The results of the present study are in agreement with the findings of Balwinder Singh Dhote $e t$ al., (2005), investigation indicated that Immuplus $(25 \mathrm{mg} / \mathrm{kg}$ body weight $)$ has potentiating effect on the paraspecific responses against $\mathrm{ND}$ and IBD antigens as detected by TLC, ALC, NBT and for IL-1 and IL-2 ELISA test in chicks.

\section{Heterophil and lymphocyte ratios}

The results of the present study revealed that there was no significant difference in $\mathrm{H}: \mathrm{L}$ in Giriraja fowl fed with supplementing herbal immunomodulator both in form of powder and liquid (with and without vaccine) and levamisole powder (with and without vaccine). Among the various treatment groups, highest $\mathrm{H}: \mathrm{L}$ value (0.14) was recorded in control fed group $\left(\mathrm{T}_{1}\right)$ as against the lowest value (0.005) recorded in groups supplemented with herbal immunomodulator liquid without and with vaccine $\left(\mathrm{T}_{6}\right.$ and $\left.\mathrm{T}_{7}\right)$. 
Table.1 Effect of herbal immunomodulator and Levamisole on immune organs (gm/100gm body weight) in Giriraja birds

\begin{tabular}{|l|l|l|l|l|}
\hline \multicolumn{2}{|c|}{ Treatment } & \multicolumn{3}{l|}{ Organ weight (gm/100gm body weight) } \\
\cline { 3 - 5 } \multicolumn{2}{|l|}{} & Spleen & $\begin{array}{l}\text { Bursa of } \\
\text { Fabricicus }\end{array}$ & Thymus \\
\hline $\mathrm{T}_{1}$ & Control & $0.19 \pm 0.02$ & $0.097 \pm 0.02$ & $0.44 \pm 0.03^{\mathrm{ab}}$ \\
\hline $\mathrm{T}_{2}$ & Control + levamisole without vaccine & $0.21 \pm 0.01$ & $0.094 \pm 0.04$ & $0.47 \pm 0.04^{\mathrm{ab}}$ \\
\hline $\mathrm{T}_{3}$ & Control + levamisole with vaccine & $0.22 \pm 0.02$ & $0.079 \pm 0.02$ & $0.56 \pm 0.06^{\mathrm{a}}$ \\
\hline $\mathrm{T}_{4}$ & $\begin{array}{l}\text { Control }+ \text { HIM powder without } \\
\text { vaccine }\end{array}$ & $0.21 \pm 0.02$ & $0.099 \pm 0.01$ & $0.49 \pm 0.04^{\mathrm{a}}$ \\
\hline $\mathrm{T}_{5}$ & Control + HIM powder with vaccine & $0.21 \pm 0.01$ & $0.081 \pm 0.01$ & $0.36 \pm 0.04^{\mathrm{b}}$ \\
\hline $\mathrm{T}_{6}$ & Control + HIM liquid without vaccine & $0.19 \pm 0.01$ & $0.056 \pm 0.01$ & $0.44 \pm 0.03^{\mathrm{ab}}$ \\
\hline $\mathrm{T}_{7}$ & Control + HIM liquid with vaccine & $0.21 \pm 0.01$ & $0.056 \pm 0.01$ & $0.43 \pm 0.03^{\mathrm{ab}}$ \\
\hline
\end{tabular}

Table.2 Effect of herbal immunomodulator and Levamisole on HI titre against NDV in Giriraja birds

\begin{tabular}{|l|l|l|l|}
\hline \multicolumn{2}{|c|}{ Treatment } & \multicolumn{2}{c|}{ HI titer } \\
\cline { 3 - 4 } & Control & III week & VIII week \\
\hline$T_{1}$ & Control + levamisole without vaccine & $3.60 \pm 0.78^{\mathrm{b}}$ & $13.80 \pm 5.77$ \\
\hline $\mathrm{T}_{2}$ & Control + levamisole with vaccine & $23.60 \pm 7.53^{\mathrm{a}}$ & $6.60 \pm 1.27$ \\
\hline $\mathrm{T}_{3}$ & Control + HIM powder without vaccine & $3.00 \pm 0.61^{\mathrm{b}}$ & $11.40 \pm 6.00$ \\
\hline $\mathrm{T}_{4}$ & Control + HIM powder with vaccine & $19.60 \pm 5.48^{\mathrm{a}}$ & $9.20 \pm 2.85$ \\
\hline $\mathrm{T}_{5}$ & Control + HIM liquid without vaccine & $2.80 \pm 0.33^{\mathrm{b}}$ & $4.80 \pm 0.90$ \\
\hline $\mathrm{T}_{6}$ & Control + HIM liquid with vaccine & $17.60 \pm 5.31^{\mathrm{ab}}$ & $9.20 \pm 1.20$ \\
\hline $\mathrm{T}_{7}$ & & & \\
\hline
\end{tabular}

Table.3 Effect of herbal immunomodulator and Levamisole on antibody titer against IBDV in Giriraja birds

\begin{tabular}{|r|l|l|l|}
\hline \multicolumn{2}{|l|}{ Treatment } & Antibody titer \\
\cline { 2 - 4 } & III week & VIII week \\
\hline $\mathrm{T}_{1}$ & Control & $2197.90 \pm 147.98$ & $1684.90 \pm 197.09^{\mathrm{b}}$ \\
\hline $\mathrm{T}_{2}$ & Control + levamisole without vaccine & $2272.10 \pm 124.93$ & $2201.20 \pm 172.07^{\mathrm{a}}$ \\
\hline $\mathrm{T}_{3}$ & Control + levamisole with vaccine & $1977.20 \pm 169.53$ & $1829.60 \pm 191.31^{\mathrm{ab}}$ \\
\hline $\mathrm{T}_{4}$ & Control + HIM powder without vaccine & $2322.00 \pm 147.32$ & $1721.40 \pm 96.73^{\mathrm{b}}$ \\
\hline $\mathrm{T}_{5}$ & Control + HIM powder with vaccine & $2239.20 \pm 163.83$ & $2016.80 \pm 52.50^{\mathrm{ab}}$ \\
\hline $\mathrm{T}_{6}$ & Control + HIM liquid without vaccine & $2374.60 \pm 160.98$ & $2167.30 \pm 127.97^{\mathrm{a}}$ \\
\hline $\mathrm{T}_{7}$ & Control + HIM liquid with vaccine & $1921.00 \pm 199.37$ & $2236.10 \pm 114.87^{\mathrm{a}}$ \\
\hline
\end{tabular}


Table.4 Effect of herbal immunomodulator and Levamisole on blood parameters (H: L) in Giriraja birds

\begin{tabular}{|l|l|l|}
\hline \multicolumn{2}{|l|}{ Treatment } & H:L \\
\hline $\mathrm{T}_{1}$ & Control & $0.14 \pm 0.04^{\mathrm{a}}$ \\
\hline $\mathrm{T}_{2}$ & Control + levamisole without vaccine & $0.04 \pm 0.01^{\mathrm{b}}$ \\
\hline $\mathrm{T}_{3}$ & Control + levamisole with vaccine & $0.01 \pm 0.004^{\mathrm{b}}$ \\
\hline $\mathrm{T}_{4}$ & Control + HIM powder without vaccine & $0.01 \pm 0.001^{\mathrm{b}}$ \\
\hline $\mathrm{T}_{5}$ & Control + HIM powder with vaccine & $0.01 \pm 0.001^{\mathrm{b}}$ \\
\hline $\mathrm{T}_{6}$ & Control + HIM liquid without vaccine & $0.005 \pm 0.001^{\mathrm{b}}$ \\
\hline $\mathrm{T}_{7}$ & Control + HIM liquid with vaccine & $0.005 \pm 0.001^{\mathrm{b}}$ \\
\hline
\end{tabular}

The present findings are in accordance with the findings of Nidhi Singh et al., (2008), who reported that heterophill count, as evinced by the analysis of variance found that it decreased with the supplementation of herbal formulations (amla plus turmeric powder each (a $5 \mathrm{gm} / \mathrm{Kg}$ of feed) in the feed irrespective of the seasons. This decrease in heterophil count was highly significant in seasons like summer, winter and rainy. This observation proves the immuno modulating effect of herbal preparations.

References

Al-Sultan. 2003. The Effect of Curcuma longa (Turmeric) on Overall Performance of Broiler Chickens. Int. J. Poultry Sci., 2(5): 351-353.

Durrani, F.R., Mohammad, Ismail, Asad, Sultan., Suhail, S.M., Naila, Chand and Durrani, Z. 2006. Effect of different levels of feed added turmeric (Curcuma longa) on the performance of broiler chicks. J. Agri. Biol. Sci., 1: 9-11.

Ganguly, S. and Prasad, A. 2010. Role of plant extracts and cow urine distillate as immunomodulator in comparison to Levamisole - A Review. J. Immunol. Immunopathol., 12(2): 91-94.

Nidhi Singh, J.P., Singh. and Rajput, M.K.S. 2008. Hematological alterations in broiler chicks during different seasons supplemented with herbal formulations. Vet. World, 1(4): 110-112.

Toghyani, M., Ghasemi, A., Tabeidian, S.A. 2015. The Effect of Different Levels of Seed and Extract of Harmal (Peganum harmala L.) on Immune Responses of Broiler Chicks. Int. J. Biol. Food, Vet. Agri. Engi., 9(1).

Ziaran, H., Rahmani, H.R. and Pourreza, J. 2005. Effect of dietary oil extract of propolis on immune response and broiler performance. Pak. J. Biol. Sci.,. 8: $1485-1490$.

\section{How to cite this article:}

Dharmaraj, G.Y., Jayanaik, H.C. Indresh and Munegowda, T. 2017. Effect of Herbal Immunomodulator on Immune Organ and Immunological Parameteres in Giriraja Birds. Int.J.Curr.Microbiol.App.Sci. 6(8): 3740-3746. doi: https://doi.org/10.20546/ijcmas.2017.608.451 